\title{
An Application Research of CBL and PBL in the Neurosurgery Clinical Teaching
}

\author{
Tao Yang \\ Yellow River Central Hospital \\ Zhengzhou, China 450003
}

\begin{abstract}
In this research, we tried to explore the effect of applying case-based learning (CBL) and problem-based learning (PBL) in Neurosurgery Clinical Teaching. We Chose 67 clinical medical students in neurosurgery of Yellow River Central Hospital from March 2015 to November 2016 and randomly divided them into experimental group ( 23 cases), CBL group ( 22 cases) and PBL group ( 22 cases). In the experimental group, teaching method of CBL and PBL were combined. In the CBL group and PBL group, teaching methods of CBL and PBL were adopted respectively. After the internship, professional knowledge and basic clinical operating skills as well as questionnaire were used to evaluate the teaching effects by these three teaching modes. The results showed that the scores of students' professional knowledge and basic clinical operating skills in experimental group were better than those of CBL group and PBL group. Meanwhile, students' clinical thinking abilities and theory \& practice connecting abilities were better than those in CBL and PBL group. The conclusion is that the combination of CBL and PBL can improves teaching effect, and is worthy of promotion in clinical internship.
\end{abstract}

Keywords-case-based learning; problem-based learning; neurosurgery; clinical teaching

\section{INTRODUCTION}

Under the current complicated medical environment, the aim of medical colleges and universities is to cultivate medical talents with a sense of innovation, high comprehensive ability and high quality. CBL (case-based learning) is an effective teaching method with which the teacher analyzes and discusses the relevant theoretical knowledge based on a typical clinical case in the teaching of students. The teaching model can improve the students' ability of analyzing and solving problems, and realize the purpose of combining theory with practice. PBL (problembased learning) is a problem-based and student-centered teaching model. The characteristics of the Major of Neurosurgery are that it is very professional and the patients are often have a critical disease, poor prognosis and risky treatment. However, in most colleges and universities, students don't have sufficient teaching hours and practice time. Therefore, it is quite a difficult task to let students master a wide range of knowledge and practical skills in a short period of time. Based on all of the above, we made great effort to reform our teaching method and models in order to improve our teaching efficiency. The results are reported as follows.

\section{ThE DESIGNING OF THE RESEARCH}

\section{A. The Researching Subjects}

We Choose 67 clinical medical students who are doing clinical practice in neurosurgery of our hospital from March 2015 to October 2016 and randomly divided them into experimental group, CBL group and PBL group. The experimental group included 23 cases, 12 males and 11 females with an average age of 21.5; The CBL group included 22 cases, 11 males and 11 females with an average age of 21.5; The PBL group included 22 cases, 11 males and 11 females with an average age of 22 . The differences among the three groups was not statistically significant $(\mathrm{P}>0.05)$.

\section{B. The Researching Contents}

All the three groups of students were conducting practice in the department of neurosurgery, and they mainly dealt with The Brain Trauma, The Tumor and The Cerebrovascular disease. For CBL group of students who were conducting practice of brain injury, we played video of traffic accident for them with multimedia and provided medical history. We had analysis and discussion about the means of examination, diagnosis and prediction. We offered the actual inspection methods and results, and analyzed the clinical symptoms and signs, and we also helped students revise the initial diagnosis and prob into occurrence and development of disease. The operative findings, complications and prognosis as well as the basic knowledge of intracranial hypertension were also related. The other diseases were also learned through a combination of typical cases with multimedia based on the deep analysis and discussion to mobilize the enthusiasm of students and improve their critical thinking ability.

The PBL group teaching was divided into five stages, namely the questioning, proposing hypothesis, data collecting, verifying hypothesis and making summary. We adopted group work and one teacher was to give guidance to 2-3 students. The teacher instructed the students to inquire about the medical history and ask patients to have common physical examine and specialist examine. Students were asked to refer to references, discuss preliminary diagnosis 
and general rationale. Then the teacher provided students with the information of patients, and arrange students to do self-study. Finally, the analysis and discussion were conducted once again focusing on previous problems. Students were required to list the important theories and conduct self-study by means of referring to books and asking the others for help. For the third discussion, the teachers would summarize, analyze, solve the problem of students, and sort out the professional knowledge to help students fully digest what they have learned. Every 3 days, a cycle of PBL teaching was conducted.

The experimental group combined the CBL teaching and PBL teaching together and CBL and PBL were conducted one after another. According to the theory and case study, the basic clinical skills were taught to students through first demonstration of teachers, and then hand to hand guidance.

\section{The Evaluating Methods of Teaching Effects}

After the internship, professional knowledge and basic clinical operating skills as well as questionnaire were used to evaluate the teaching effects by these three teaching models. The professional knowledge tested students' basic theory and case analysis ability, Including history collection, specialist examination, pathogen and diagnostic analysis, data analysis and the treatment plan and so on. The basic clinical skills tests focused on the Lumbar puncture including preoperative preparation, body position and puncture site, toxicity and anesthesia and lumbar puncture etc. Questionnaire Included clinical thinking abilities, reading abilities, theory combining clinical practice abilities, interests in practice, the improvement of knowledge comprehension and the acceptance of the teaching method. Professional knowledge written examination included the objective basic theories $(50 \%)$ and case analysis (50\%), with a total score of 100 points. The total score of basic clinical skills is 50 points.

\section{The Statistical Methods}

The SPSS 17.0 software was used for statistical analysis, and the evaluative materials were shown as $\bar{X} \pm \mathrm{s}$ and tested by $\mathrm{X}^{2}$. The T-test was used for comparison between groups, and Statistical significance was ignored if $\mathrm{P}>0.05$

\section{The FIGURES PRESENTATION AND ANALYSIS}

\section{A. The Comparison of Professional Knowledge among the Three Groups}

The scores of the experimental group were higher than that of CBL and PBL group, and the difference was statistically significant $(\mathrm{P}<0.05)$. In the aspect of pathogen and diagnostic analysis as well as the data analysis and the treatment plan, the results of the experimental group and the PBL group were better than the CBL group $(\mathrm{P}<0.05)$ and the results in other aspects among the three groups were not statistically Significant $(\mathrm{P}>0.05)$ "Table I".

\section{B. The Comparison of the Basic Clinical Skills among the Three Groups}

The basic clinical skills of the experimental group were higher than $\mathrm{CBL}$ and $\mathrm{PBL}$ group and the difference was statistically significant $(\mathrm{P}<0.05)$ "Table II".

\section{The Comparison of the Questionnaire Results among the Three Groups}

The clinical thinking abilities and the theory \& practice abilities of the experimental group were obviously better than that of CBL and PBL group $(\mathrm{P}<0.05)$. In the aspects of improving students' interests, understanding knowledge, and the tendency of choice of teaching methods, there was no significant difference among the three groups $(\mathrm{P}=\mathrm{P}>0.05)$ "Table III".

TABLE I. The COMParison of Professional KNOWLEDGE AMONG THE THreE Groups (SCORES, $\overline{\mathrm{X}} \pm \mathrm{S}$ )

\begin{tabular}{|c|c|c|c|c|c|c|c|}
\hline Groups & $\begin{array}{c}\text { Basic Theories } \\
(\mathbf{5 0})\end{array}$ & $\begin{array}{c}\text { History } \\
\text { Collection (10) }\end{array}$ & $\begin{array}{c}\text { Specialty } \\
\text { Check-up (10) }\end{array}$ & $\begin{array}{c}\text { Pathogenesis } \\
\text { And Therapy } \\
\text { (10) }\end{array}$ & $\begin{array}{c}\text { Imaging } \\
\text { Analysis (10) }\end{array}$ & $\begin{array}{c}\text { Treatment Plan } \\
(10)\end{array}$ & $\begin{array}{c}\text { Total } \\
\text { Scores } \\
(\mathbf{1 0 0}) \\
\end{array}$ \\
\hline $\begin{array}{l}\text { The experimental } \\
\text { group }(n=23)\end{array}$ & $44.42 \pm 3.02$ & $8.65 \pm 1.02$ & $8.50 \pm 0.82$ & $9.04 \pm 0.86 \#$ & $8.85 \pm 0.80$ & $9.16 \pm 0.90 \#$ & $\begin{array}{l}88.52 \pm 6.05 \\
*\end{array}$ \\
\hline The CBL group $(n=22)$ & $40.04 \pm 3.06$ & $8.15 \pm 0.78$ & $8.01 \pm 0.80$ & $7.80 \pm 0.82$ & $8.26 \pm 0.67$ & $7.55 \pm 0.72$ & $79.81 \pm 4.37$ \\
\hline The PBL group $(n=22)$ & $39.88 \pm 3.16$ & $8.08 \pm 0.86$ & $8.01 \pm 0.86$ & $8.43 \pm 0.80 \#$ & $8.10 \pm 0.62$ & $8.46 \pm 0.74 \#$ & $\begin{array}{l}80.96 \pm 4.48 \\
*\end{array}$ \\
\hline
\end{tabular}

${ }^{\text {a. }}$ Compared with $\mathrm{CBL}$ group and $\mathrm{PBL}$ group, $* \mathrm{P}<0.05$, Compared with $\mathrm{CBL}$ group, \# $\mathrm{P}<0.05$

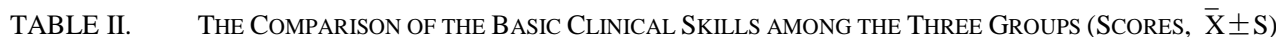

\begin{tabular}{|c|c|c|c|c|c|c|}
\hline Groups & $\begin{array}{c}\text { Preoperation } \\
\text { Preparation (5) }\end{array}$ & $\begin{array}{l}\text { Body Position } \\
\text { and Puncture } \\
\text { Site (10) }\end{array}$ & $\begin{array}{l}\text { Disinfection and } \\
\text { Anesthesia (10) }\end{array}$ & $\begin{array}{c}\text { Lumbar } \\
\text { Puncture (20) }\end{array}$ & $\begin{array}{r}\text { Terminal } \\
\text { Quality (5) }\end{array}$ & $\begin{array}{l}\text { Total Scores } \\
\text { (100) }\end{array}$ \\
\hline $\begin{array}{l}\text { The experimental group } \\
(n=23)\end{array}$ & 4. $51 \pm 0.45$ & $8.72 \pm 0.82$ & $8.70 \pm 0.92$ & $17.62 \pm 1.76$ & $4.462 \pm 0.60$ & $44.01 \pm 4.64 *$ \\
\hline The CBL group $(n=22)$ & $4.01 \pm 0.40$ & $8.01 \pm 0.76$ & $8.06 \pm 0.68$ & $15.45 \pm 1.52$ & $4.01 \pm 0.40$ & $39.54 \pm 3.70$ \\
\hline The PBL group $(n=22)$ & $3.92 \pm 0.38$ & $7.90 \pm 0.70$ & $8.10 \pm 0.72$ & $15.40 \pm 1.62$ & $3.98 \pm 0.40$ & $39.30 \pm 3.50$ \\
\hline
\end{tabular}


TABLE III. The COMPARISON OF THE QUESTIONNAIRE RESUlTS AMONG THE THREE GROUPS [N (\%)]

\begin{tabular}{|c|c|c|c|c|c|c|}
\hline Groups & $\begin{array}{c}\text { Clinical } \\
\text { Thinking }\end{array}$ & $\begin{array}{c}\text { Literature } \\
\text { Reading }\end{array}$ & $\begin{array}{l}\text { Theories \& } \\
\text { Practice } \\
\text { Connecting }\end{array}$ & $\begin{array}{l}\text { Internship } \\
\text { Interests }\end{array}$ & Comprehension & $\begin{array}{c}\text { Acceptance of } \\
\text { the Learning } \\
\text { Methods }\end{array}$ \\
\hline The experimental group $(n=23)$ & $21(91.30) *$ & $19(82.60)$ & $22(95.65) *$ & $15(65.22)$ & $19(82.61)$ & $16(69.57)$ \\
\hline The CBL group $(\mathrm{n}=22)$ & $16(62.72)$ & $18(81.82)$ & $15(68.18)$ & $14(63.64)$ & $18(81.82)$ & $16(72.73)$ \\
\hline The PBL group $(n=22)$ & $16(72.73)$ & $18(81.82)$ & $16(72.73)$ & $15(68.18)$ & $17(86.36)$ & $15(68.18)$ \\
\hline
\end{tabular}

\section{DISCUSSION}

The level of medicine depends largely on clinical practice. In the past, the medical education was mainly based on the teacher's transmission of book knowledge and students' passive acceptance. And in the practice stage, the students just depended on self-study and self- inquiring, thus the consequences was not satisfactory at all.Surgery is a discipline combined with the technology, the science and the art. The neurosurgery practice has a very strong specialty and practicality and it is the bridge leading to the hall of science and technology. As clinician medical educators, we need to constantly update and refresh our teaching beliefs and teaching methods and try every best to strengthen students' ability of active learning, their abilities of discovering and solving problems and the abilities of exploring and innovating.

The core of CBL is to employ typical cases and genuine problems into the group-discussion teaching process, in which the teacher is a guider while the students are the main body. The purpose of CBL is to provide students with simulated clinical environment, help them form clinical thinking as soon as possible, improve their initiative and cultivate their ability of self-learning and innovation. Tradition neurosurgery practice usually goes like this: The teacher taught the content of teaching materials first, and then discussed the clinical cases with the students, which included the history of the case, body clinical diagnosis and treatment such as operation. Due to the boring teaching materials and teaching methods, it's very difficult to simulate students' learning interests and desire, and the practice efficiency was poor and unsatisfactory. With CBL teaching method, the students learned how to understand the condition, how to collect the history, and how to diagnose the disease, which greatly helped them to grasp the main problems of the disease, and make accurate judgment and flexible processing.

From the clinical point of view, in PBL teaching, we first proposed questions, and then solved the problem under students' independent thinking. In the process of learning, students looked for various materials through their own consulting and inquiring. They used their own ways of thinking for the diagnosis and treatment of disease and they organized all kinds of discussion activities. All of the above learning behaviors not only greatly enhanced their theoretical and practical abilities but also largely improved their communicative abilities. This teaching model is very effective in the cultivation of creative and pioneering talents in the modern medical system, whose advantages is quite superior to traditional teaching methods. In this study, the scores of PBL group of students were slightly better than the group CBL students in the aspects pathogenesis, diagnostic and treatment $(\mathrm{P}<0.05)$, which proved that the PBL teaching method was indeed more superior in mobilizing students' learning enthusiasm and initiative.

Both the PBL and CBL teaching models emphasize the importance of students' Initiative spirit and the combination of book knowledge, referential materials with clinical cases, but the teaching aim and methods are different. CBL tends to cultivate students' abilities of independent analysis and judgment while PBL focuses on the cultivation of students' autonomous learning, analysis and problem solving abilities; CBL needs the teacher to explain the theoretical knowledge while PBL needs the students to collect relevant information on their own; CBL is not limited by the conditions and the tasks can be completed in the classroom while PBL needs students to collect materials both inside and outside classroom. At present, the aim of medical teaching is to cultivate students' thinking abilities, flexible clinical practice abilities, theoretical and practical abilities, and the abilities of tacking realistic problems. Therefore, it is unwise to separate the two teaching methods apart, and we suggest combing the two together to achieve different teaching purposes.

In this study, the experimental group students were trained with a combination of PBL and CBL according to their different aptitude, which was completely different from traditional teaching ideas. Therefore, the scores of experimental group were obviously higher than CBL and PBL group and the difference was statistically significant $(\mathrm{P}<0.05)$. This further illustrated the combination of $\mathrm{CBL}$ and PBL in the neurosurgery practice teaching could effectively help students improve their learning efficiency and learning effect and expand the breadth and depth of students' knowledge.

\section{CONCLUSION}

The combination of CBL and PBL is an effective teaching model in the neurosurgery practice and it is worthy promotion in clinical internship. Of course, there are also some limitations we need to be aware of. This teaching model makes the teacher under great pressure because they have to devote much extra time to do teaching planning and prepare the cases and analysis. Meanwhile, students also feel stressful for autonomous learning and inquiring. Therefore, in the clinical teaching, we need to be flexible and creative and adopt individualized instructions. 


\section{REFERENCES}

[1] Jill E, David D, Samilia E, ed al.The effectiveness of case-based learning in heath professional education. A BEME systematic review: BEME Guide No.23 [J].Med Teach, 2012, 34(6):421-444.

[2] Neill PA.The role of basic science in a problem-based learning clinical curriculum [J].Med Educ, 2000, 34 (8): 608-613.

[3] Albanese M.Problem-based learning: why curricula are likely to show little effect on knowlege and clinical skills [J]. Med Educ, 2000, 34(9): 729-738

[4] Linda C, Palricia W, David B. Case-based, problem-based learning Information literacy for the real world [J]. Res Strateg, 2001, (18):181-190.

[5] Jane J. Case-based learning and reticence in a bilingual context: perceptions of business students in Hong Kong [J]. System, 2003, 31 (4): $457-469$.

[6] Dolmans D, Gijbels D. Research on problem-based learning: future challenges [J]. Med Educ, 2013, 47 (2): 214-218.

[7] Dupuis RE, Persy AM. Use of case-based learning in a clinical pharmacokinelics course [J]. Am J Pharm Educ, 2008, 72 (2): 29.

[8] Nadershahi NA, Bender DJ, Beck L, et al. An overview of case based and problem -based learning methodologies for dental education [J]. J Dens Educ, 2013, 77 (10):1300-1305. 